\title{
NORMATIVE MEASUREMENTS OF NOISE AT CNC MACHINES WORK STATIONS
}

\author{
Dariusz Mika', Jerzy Józwik² \\ 1 The State School of Higher Education in Chełm, The Institute of Technical Sciences and Aviation, 54 Pocztowa \\ Street, 22-100 Chełm, Poland, e-mail:dmika@pwsz.chelm.pl \\ 2 Department of Production Engineering, Mechanical Engineering Faculty, Lublin University of Technology, \\ 36 Nadbystrzycka Street, 20-816 Lublin, Poland, e-mail: j.jozwik@pollub.pl
}

Received: 2016.03.06

Accepted: 2016.04 .25

Published: 2016.06.01

\begin{abstract}
Minimisation of noise at a workstation is among fundamental tasks for maintaining safety at work, both in terms of health (the auditory system in particular) as well as work comfort. Thus, it is very important to systematically monitor noise levels by carrying out reliable measurements at a workstation. The method of performing noise measurements at workstations of specific machines is normalised so the results of such measurements for different machines is comparable. This paper presents noise measurements for DMC 635 numerically controlled milling machine, performed in accordance with PN ISO 230-5:2002 norm. The results showed that the level of noise at the operator's workstation significantly exceeds the norm at certain machining parameters. The results of tests are concluded as detailed recommendation for the CNC machine tool operator to use hearing protection when at work.
\end{abstract}

Keywords: noise, noise measurement, acoustic pressure, acoustic absorption, CNC machines.

\section{INTRODUCTION}

Noise is one of the most tiring factors in work environment, whose damage to human organism is difficult to assess $[2-3,20]$. At workplaces in industrial conditions, every worker is exposed to noise levels that very often exceed permissible values. Noise is frequently defined as any sound which, in given conditions, is undesirable, tiring or harmful to human health [2]. Damages in hearing caused by noise are the most common occupational disease in Europe and present about one third of all work-related diseases [16]. Safety is a wide subject of interest whose proper application allows obtaining safe product and working environment [6-7, 14-15, 17].

The harmful and tiring effects of noise depend on its intensity, frequency and changes in time, long-lasting effects and the contents of inaudible components, as well as the characteristics of the operator such as age, mental condition, health and individual sensitivity to sounds. Prolonged exposure to high levels of noise has highly negative effect on a person and their health. High levels of noise have negative effect on well-being, and in extreme cases may lead to hearing damage. Hearing protection must be used if the level of noise is $85 \mathrm{~dB}$ or higher [2, 4, 18-20].

Minimisation of noise is exceptionally important in machinery industry, where constant operation of machinery and devices entails exposition to high levels of noise. Examples of this are production halls with CNC machines [4-5, 8-13]. Evaluation of that kind of noise is the basis for using different methods of noise reduction or to recommend personal hearing protection for the CNC operator [18-19]. Reliable measurement of noise created a need to prepare a procedure for measuring noise emission at $\mathrm{CNC}$ machines workstations. A comprehensive procedure of measur- 
ing acoustic strength of noise emitted by $\mathrm{CNC}$ machines is presented in Polish norm PN-ISO 230-5:2002. The norm contains information on basic conditions for carrying out tests of emission and acoustic strength, test methods, necessary measuring equipment and the procedure for analysing the results: EN ISO 11201:2012; EN ISO 11202:2012; EN ISO 11203:2010; EN ISO 11204:2010; EN ISO 11205:2010; EN ISO 11689:2000; EN ISO 11689:2000/AC:2009; EN ISO 11690-2:2000; EN ISO 11690-3:2002; EN ISO 4871:2010; EN ISO 9612:2011; EN-01307: 1994; EN-ISO 1999:2000; EN-ISO 230-5; EN-ISO 230-5:2002; PN-N-01307:1994, ISO 8525:2008, Directive 98/37EC of the European Union.

\section{METHODOLOGY}

The measurement of acoustic pressure of noise emitted by a CNC machine was carried out in accordance with PN-ISO 230-5:2002 Standard. According to the norm, the basic parameters measured at every position of the microphone for every work time span or production cycle of the machine are the following:

- $\mathrm{L}_{\mathrm{pA}}^{\prime}-$ mean acoustic pressure value, corrected with the frequency characteristics $\mathrm{A}$, for a working $\mathrm{CNC}$ machine,

- $\mathrm{L}_{\mathrm{pA}}^{\prime}$ - mean acoustic pressure value, corrected with the frequency characteristics A, generated by environmental noise,

- $\mathrm{L}_{\mathrm{pCpeak}}-$ peak value of the acoustic pressure corrected with the frequency characteristics $\mathrm{C}$.

The scope of the tests includes measurements of the noise emitted by a DMC 635 Eco milling machine equipped with a CNC system. The diagram of the test stand, including the measuring

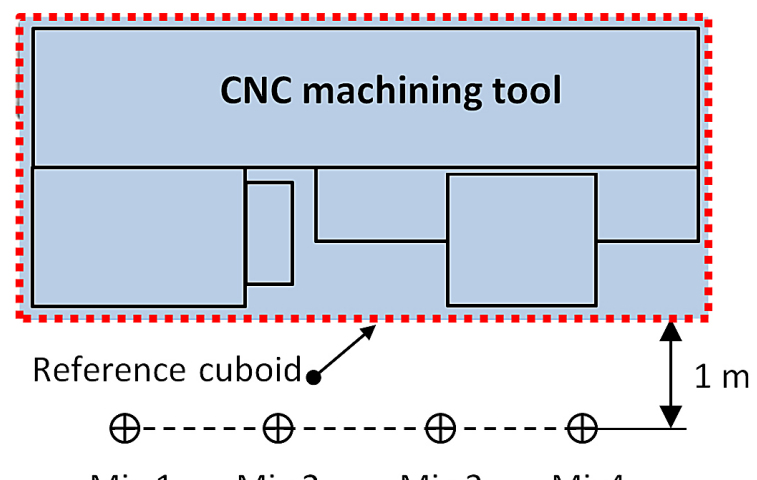

Mic 1 Mic $2 \quad$ Mic $3 \quad$ Mic4

Fig. 1. Diagram of test stand and location of measuring points (microphones) points (places where the microphones are positioned) is presented in Figure 1. The measurements were performed with microphones placed in four points at a distance of one metre from the walls of so-called reference cuboid, at a height of $1.55 \pm 0.075 \mathrm{~m}$ above the floor (Fig. 1).

The value of the highest emission level of acoustic pressure should be recorded as the level of the acoustic pressure of the tested machine. The place where this value was measured should be recorded. The measurements of acoustic emission of the tested CNC machine were performed in an $11.2 \times 14.30 \times 3.7 \mathrm{~m}$ room, with the use of a four-channel acoustic meter (Svantec 958) and four measuring microphones Svantec SV22 and a Svantec SV12L pre-amplifier. The measurements were performed for a standard work cycle of the tested CNC machine. The test was realised by machining an $80 \times 60 \times 10 \mathrm{~mm}$ solid piece of aluminium alloy with variable technological parameters of the process, as presented in Table 1 .

Table 1. Machining conditions during noise measurements at a $\mathrm{CNC}$ machine tool station.

\begin{tabular}{|c|c|c|c|c|c|}
\hline \multicolumn{6}{|c|}{ Machining conditions } \\
\hline Depth of cut ap [mm] & 1 & 1.5 & 2 & 2.5 & 3 \\
\hline $\begin{array}{l}\text { Feed motion speed fz } \\
\text { [mm/tooth] }\end{array}$ & 0.1 & 0.15 & 0.2 & 0.25 & 0.3 \\
\hline $\begin{array}{l}\text { Cutting speed vc }[\mathrm{m} / \\
\mathrm{min}]\end{array}$ & 420 & 470 & 520 & 570 & 620 \\
\hline Tool diameter $[\mathrm{mm}]$ & \multicolumn{5}{|c|}{12} \\
\hline Tool material & \multicolumn{5}{|c|}{ High-speed alloy steel } \\
\hline Sample size [mm] & \multicolumn{5}{|c|}{$80 \times 60 \times 10$} \\
\hline $\begin{array}{l}\text { Machined piece } \\
\text { material }\end{array}$ & \multicolumn{5}{|c|}{ Aluminium alloy } \\
\hline $\begin{array}{l}\text { Room dimensions } \\
\mathrm{l} \times \mathrm{b} \times \mathrm{h}[\mathrm{mm}]\end{array}$ & \multicolumn{5}{|c|}{$11200 \times 14300 \times 3700$} \\
\hline
\end{tabular}

An analysis of test results was carried out with Svan $\mathrm{PC}++$ software. Measurement time was 60 seconds. In order to determine acoustic pressure emitted by the machine, we introduce to the measured levels of emission of acoustic pressure $\mathrm{L}_{\mathrm{pA}}$ background noise correction and local environmental correction $\mathrm{K}_{\mathrm{A}}$, excluding peak levels of acoustic pressure emission $\mathrm{L}_{\mathrm{pCpeak}}$, for which no corrections are allowed. Acoustic pressure level $\mathrm{L}_{\mathrm{pA}}$ emitted by the machine should be determined depending on the level of environmental noise:

- if in a given place the difference $\Delta \mathrm{L}_{\mathrm{A}}$ between measured acoustic noise level $\mathrm{L}_{\mathrm{pA}}$ corrected with frequency characteristic A emitted by a 
$\mathrm{CNC}$ machine and the level of acoustic pressure level L" ${ }_{\mathrm{pA}}$ of environmental noise corrected with frequency characteristic A exceeds $10 \mathrm{~dB}$ (15 dB for precession level 2), the level of acoustic pressure emission in that place is (1):

$$
\mathrm{L}_{\mathrm{pA}}=\mathrm{L}_{\mathrm{pA}}^{\prime}-\mathrm{K}_{\mathrm{A}}
$$

- if in a given place $\Delta \mathrm{L}_{\mathrm{A}}$ is within the range of $3 \mathrm{~dB}$ to $10 \mathrm{~dB}(15 \mathrm{~dB}$ for precession level 2$)$, the level of emission acoustic pressure in this place is (2):

$$
L_{p, 4}=10 \lg \left[10^{0,1 L_{p 4}^{\prime}}-10^{0,1 L_{p 4}^{\prime \prime}}\right]-K_{A}
$$

The correction accounting for environmental noise level should be included for every place in which it is within $3 \mathrm{~dB}$ to $10 \mathrm{~dB}(15 \mathrm{~dB}$ for precession level 2). If it is higher than $6 \mathrm{~dB}$, the results correspond to the precision level 2 (to precision level 3 in other cases). If $\Delta \mathrm{L}_{\mathrm{A}}<3 \mathrm{~dB}$, then according to the norm the measurement is invalidated.

Local environmental correction $\mathrm{K}_{\mathrm{A}}$ takes into account the effect of reflected sound on the emission acoustic pressure in a given place of the tested CNC machine. Due to basic requirements, the environmental correction $\mathrm{K}_{\mathrm{A}}$ should not exceed $7 \mathrm{~dB}$. In the case of the orientation method presented in this work precision level 3), local environmental correction $\mathrm{K}_{\mathrm{A}}$ is determined from the following equation (3):

$$
K_{A}=10 \log \left[1+4\left(2 \pi a^{2} / A\right)\right]
$$

where: $a-$ is the distance from a given place to the closest main source of sound from the tested machine $[\mathrm{m}]$,

$A$ - is the equivalent acoustic absorbance of the surface of the tested room at a frequency of $1 \mathrm{kHz}\left[\mathrm{m}^{2}\right]$.

In the case where the main source of noise is not defined well enough, this distance should be assumed as the distance from a given place to the nearest part of the tested machine. Value A, equivalent to the acoustic absorption of the surface, is determined using one of two following methods:

- approximation method - according to this method, acoustic absorption A of a surface is determined using the following formula (4):

$$
\mathrm{A}=\alpha \cdot \mathrm{S}_{\mathrm{v}}
$$

where: $\alpha$ - mean coefficient of acoustic absorption given for a value corrected with the frequency characteristic A,

$\mathrm{S}_{\mathrm{V}}$ - total area of the surfaces limiting the test room (e.g. walls, ceiling, floor) $\left[\mathrm{m}^{2}\right]$

- reverberation method - the value of the acoustic absorption A of the surface is determined using the time of reverberation of the test room for broadband noise or impulse noise and frequency correction $\mathrm{A}$ in the receiving system. Value A expressed in square metres is determined from the Sabin formula (5):

$$
\mathrm{A}=0.16(\mathrm{~V} / \mathrm{T})
$$

where: $\mathrm{V}-$ the volume of the test room $\left[\mathrm{m}^{2}\right]$, $\mathrm{T}$ - reverberation time $[\mathrm{s}]$

Prior to performing the measurements of noise emission of the CNC machine tool, the measuring microphones, Svantec SV 30A, were calibrated. At the first stage, the level of environmental noise $\mathrm{L}_{\mathrm{pA}}$ was measured. The results are presented in Table 1 . The average environmental noise level was $\mathrm{L}_{\mathrm{pA}}=32.76 \mathrm{~dB}$.

Table 2. Compilation of the results of environmental noise level measurement corrected with frequency characteristic A

\begin{tabular}{|c|c|c|c|c|c|}
\hline Mic & Filter & Detector & $\begin{array}{c}\text { Elapsed time } \\
{[\text { hh: } \mathrm{mm}: \mathrm{ss}]}\end{array}$ & Units & $L^{\prime \prime}{ }_{p A}[\mathrm{~dB}]$ \\
\hline 1 & A & Fast & $00: 00: 07$ & $\mathrm{~dB}$ & 32.58 \\
\hline 2 & A & Fast & $00: 00: 07$ & $\mathrm{~dB}$ & 33.04 \\
\hline 3 & A & Fast & $00: 00: 07$ & $\mathrm{~dB}$ & 32.86 \\
\hline 4 & A & Fast & $00: 00: 07$ & $\mathrm{~dB}$ & 32.56 \\
\hline \multicolumn{7}{|r}{ Mean value } & $\mathbf{3 2 . 7 6}$ \\
\hline
\end{tabular}

In the first series of measurements, the cutting speed $\mathrm{v}_{\mathrm{c}}$ was changed within the range of $420 \div 620 \mathrm{~m} / \mathrm{min}$. The depth of cut and rate of feed were constant: $f_{z}=0.2 \mathrm{~mm} /$ tooth and $a_{p}=2 \mathrm{~mm}$ respectively. The results are presented in Table 3 and in Figure 2. Maximum noise level values were recorded in point Mic 1 at the cutting speed of $\mathrm{v}_{\mathrm{c}}$ $=520 \mathrm{~m} / \mathrm{min}$.

In the second series of measurements, a constant cutting speed of $\mathrm{v}_{\mathrm{c}}=520 \mathrm{~m} / \mathrm{min}$ and depth of cut of $a_{p}=2 \mathrm{~mm}$ were determined. The rate of feed of $f_{z}=0.1-0.3 \mathrm{~mm} /$ tooth changed. The results are presented in Table 4 and Figure 3. The maximum values of noise levels were recorded in point Mic 1 at the maximum rate of feed of $\mathrm{f}_{\mathrm{z}}=0.3 \mathrm{~mm} /$ tooth.

In the third series of measurements the cutting speed values were determined at the level of 
Table 3. Compilation of results of noise level measurements for the noise emitted by a CNC machine at varied cutting speed $\mathrm{v}_{\mathrm{c}}$, obtained at $\mathrm{f}_{\mathrm{z}}=0.2 \mathrm{~mm} /$ tooth, $a_{\mathrm{p}}=2 \mathrm{~mm}$

\begin{tabular}{|c|c|c|}
\hline$v_{c}[\mathrm{~m} / \mathrm{min}]$ & $L_{p A}^{\prime}[\mathrm{dB}]$ & $L_{p \text { cpeak }}[\mathrm{dB}]$ \\
\hline 420 & 59.68 & 92.29 \\
\hline 470 & 79.2 & 94.15 \\
\hline $\mathbf{5 2 0}$ & $\mathbf{8 3 . 1 3}$ & $\mathbf{9 8 . 3 4}$ \\
\hline 570 & 80.33 & 97.82 \\
\hline 620 & 81.71 & 97.94 \\
\hline
\end{tabular}

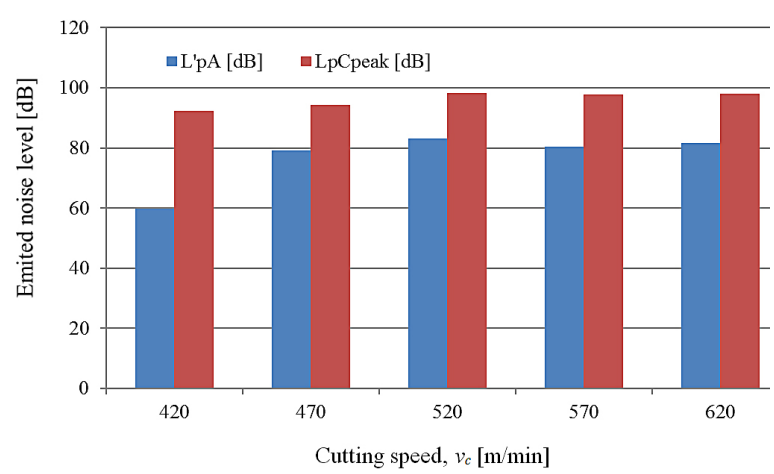

Fig. 2. Results of measurements of the noise emitted by a CNC machine in a function of cutting speed $\mathrm{v}_{\mathrm{c}}$ for the first measurement series recorded at $\mathrm{f}_{\mathrm{z}}=0.2$ $\mathrm{mm} /$ tooth and $\mathrm{a}_{\mathrm{p}}=2 \mathrm{~mm}$

Table 4. Compilation of results of noise level measurements for the noise emitted by a CNC machine at varied rates of feed $\mathrm{f}_{\mathrm{z}}$, obtained at $\mathrm{v}_{\mathrm{c}}=520 \mathrm{~m} / \mathrm{min}$, $\mathrm{a}_{\mathrm{p}}=2 \mathrm{~mm}$

\begin{tabular}{|c|c|c|}
\hline$f_{z}[\mathrm{~mm} /$ tooth $]$ & $L_{p A}^{\prime}[\mathrm{dB}]$ & $L_{p \text { cpeak }}[\mathrm{dB}]$ \\
\hline 0.1 & 78.28 & 95.7 \\
\hline 0.15 & 79.89 & 96.11 \\
\hline 0.2 & 83.13 & 98.34 \\
\hline 0.25 & 83.74 & 99.78 \\
\hline $\mathbf{0 . 3}$ & $\mathbf{8 5 . 7 6}$ & $\mathbf{1 0 3 . 8 1}$ \\
\hline
\end{tabular}

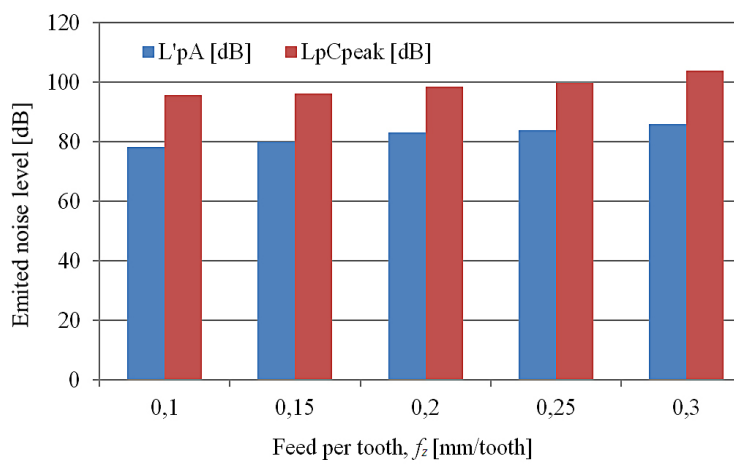

Fig. 3. Results of measurements of the noise emitted by a CNC machine in a function of cutting speed $v_{c}$ for the second measurement series recorded at $\mathrm{v}_{\mathrm{c}}=520 \mathrm{~m} / \mathrm{min}$ and $\mathrm{a}_{\mathrm{p}}=2 \mathrm{~mm}$ $\mathrm{v}_{\mathrm{c}}=520 \mathrm{~m} / \mathrm{min}$ and rate of feed $\mathrm{f}_{\mathrm{z}}=0.3 \mathrm{~mm} /$ tooth. The depth of cut was changed within $a_{p}=1 \div 3 \mathrm{~mm}$. The results are presented in Table 5 and Figure 4. The maximum values of noise levels were recorded in point Mic 1 at the maximum depth of cut of $\mathrm{a}_{\mathrm{p}}=3 \mathrm{~mm}$.

Table 5. Compilation of results of noise level measurements for the noise emitted by the $\mathrm{CNC}$ machine at varied depth of cuts $a_{p}$

\begin{tabular}{|c|c|c|}
\hline $\mathrm{a}_{\mathrm{p}}[\mathrm{mm}]$ & $L_{p A}^{\prime}[\mathrm{dB}]$ & $L_{p \text { cpeak }}[\mathrm{dB}]$ \\
\hline 1.0 & 80.36 & 99.50 \\
\hline 1.5 & 81.50 & 98.20 \\
\hline 2.0 & 85.76 & 103.81 \\
\hline 2.5 & 86.51 & 102.03 \\
\hline $\mathbf{3 . 0}$ & $\mathbf{8 8 . 3 3}$ & $\mathbf{1 0 3 . 9 7}$ \\
\hline
\end{tabular}

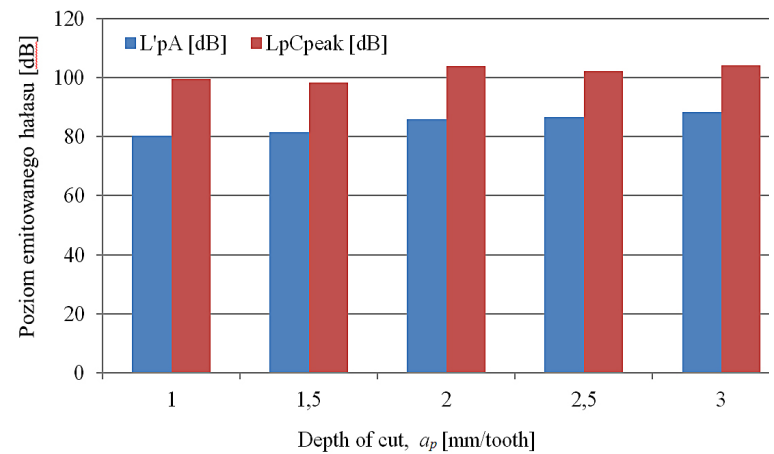

Fig. 4. Results of measurements of the noise emitted by the CNC machine in a function of depth of cut for the third measurement series, obtained for $\mathrm{v}_{\mathrm{c}}=520 \mathrm{~m} / \mathrm{min}$ and $\mathrm{f}_{\mathrm{z}}=0.3 \mathrm{~mm} /$ tooth

Figure 5 presents the results of noise measurements during the work of the $\mathrm{CNC}$ machine for every measuring channel (i.e. every microphone), taking into consideration the maximum levels (MAX), minimum levels (MIN), average levels (LEQ) and peak levels (PEAK) for both types of the corrective filter (A and $C$ ).

Maximum average level of acoustic pressure was recorded in point 1 for the following cutting parameters: $\mathrm{v}_{\mathrm{c}}=520 \mathrm{~m} / \mathrm{min}, \mathrm{f}_{\mathrm{z}}=0.3 \mathrm{~mm}, \mathrm{a}_{\mathrm{p}}=3 \mathrm{~mm}$, and it was $\mathrm{L}_{\mathrm{pA}}=88.33 \mathrm{~dB}$. This result was regarded, in accordance with the norm, as an average level of acoustic pressure for the tested CNC machine.

In order to determine local correction $\mathrm{K}_{\mathrm{A}}$, an equivalent acoustic absorption was measured using the reverberation method. To perform the measurement, a generally available source of sound and a broadband noise generator were used. The measurement of the room 
a)

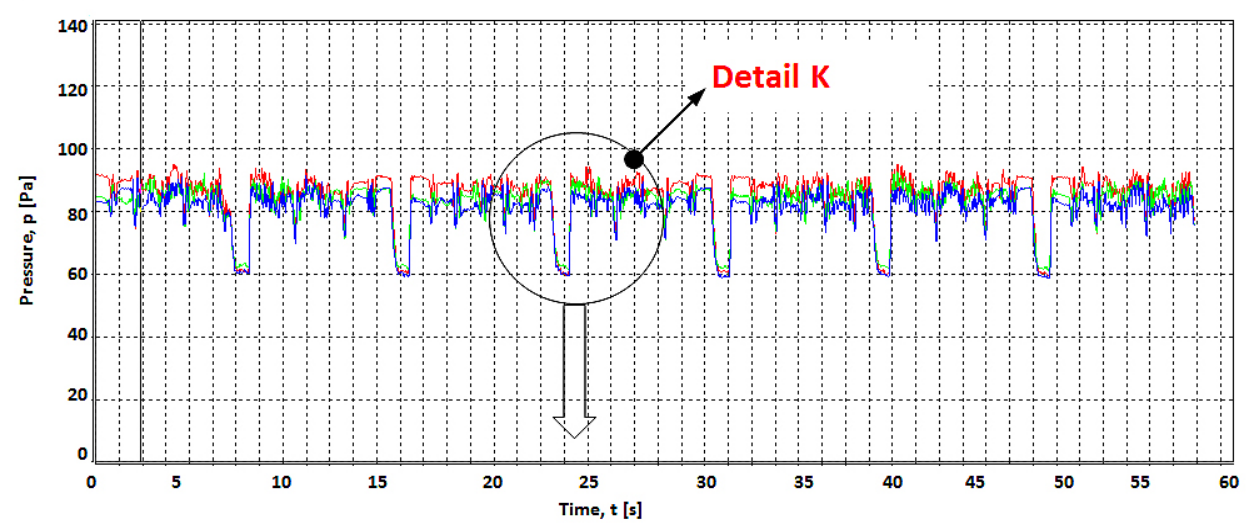

b)

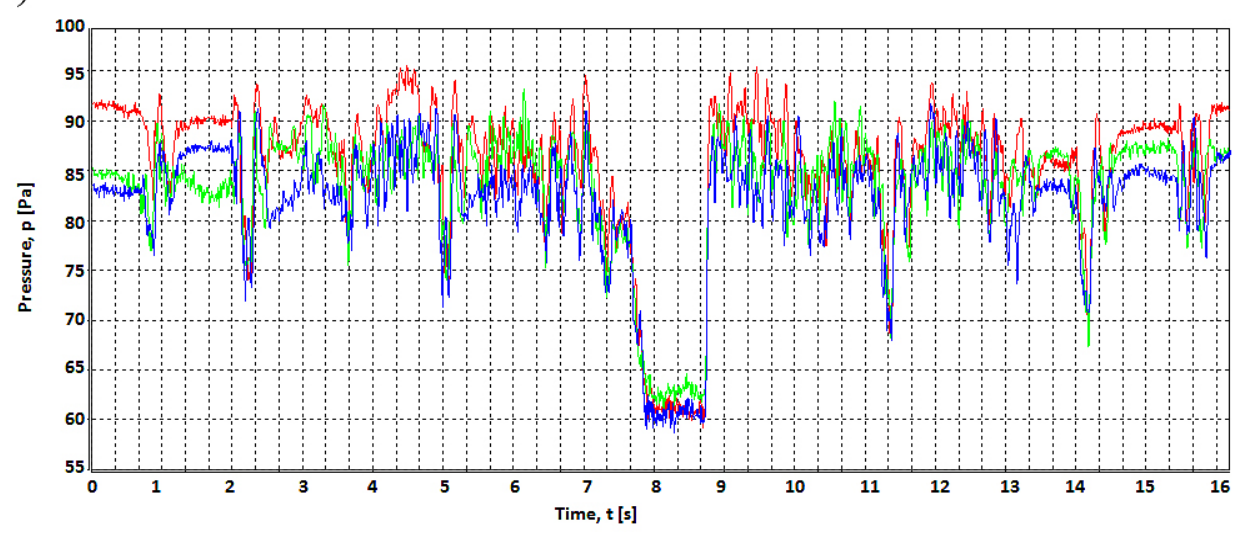

Fig. 5. Momentary values of acoustic pressure levels for four microphones recorded during the measurements: a) course of the signal during $60 \mathrm{~s}$ exposure, b) detail $\mathrm{K}$

response was performed with the use of Norsonic NOR 140 noise meter. The reverberation time for the test room was $\mathrm{T}=1.83 \mathrm{~s}$. Thus, using Sabine formula, the equivalent acoustic absorption A (for a test room of $\mathrm{V}=592.6 \mathrm{~m}^{3}$ ) was calculated.

$$
\mathrm{A}=0.16(\mathrm{~V} / \mathrm{T})=0.16(592.6 / 1.83)=51.8 \mathrm{~m}^{2}
$$

Assuming that $\mathrm{a}=1 \mathrm{~m}$, local environmental correction $\mathrm{K}_{\mathrm{A}}$ for the test room was:

$$
K_{A}=10 \log \left[1+4\left(2 \pi a^{2} / A\right)\right]=10 \log [1+4(2 \pi / 51.8)]=1.72 d B
$$

The difference $\Delta \mathrm{L}_{\mathrm{A}}$ between the measured level of acoustic pressure $\mathrm{L}_{\mathrm{pA}}$ corrected with frequency characteristic $\mathrm{A}$, emitted by the machine, and the level of acoustic pressure L" of the environmental noise corrected with frequency characteristic A during the measurements was greater than $10 \mathrm{~dB}$. Therefore, the level of acoustic pressure for the tested CNC machine was:

$$
\mathrm{L}_{\mathrm{pA}}=\mathrm{L}_{\mathrm{pA}}^{\prime}-\mathrm{K}_{\mathrm{A}}=88.33-1.72=86.61 \mathrm{~dB}
$$

Maximum peak level of acoustic pressure corrected with frequency characteristic $\mathrm{C}$ was recorded also in Mic $1\left(\mathrm{~L}_{\text {pCpeak }}=103.97 \mathrm{~dB}\right)$. According to the recommendation of the norm, the aforementioned values of pressure levels rounded to the nearest integer are the result of the measurement: $\mathrm{L}_{\mathrm{pA}}=87 \mathrm{~dB}, \mathrm{~L}_{\mathrm{pCpeak}}=104 \mathrm{~dB}$.

\section{CONCLUSIONS}

The performed measurements of acoustic emission of the tested machine tool show that at certain operation parameters (determined by the technological cutting parameters) noise norms ( 85 $\mathrm{dB})$ at a workstation are exceeded. The highest noise levels were recorded in the third stage of the tests. Maximum values were recorded at the maximum technological cutting parameters of $a_{p}=3$ $\mathrm{mm}, \mathrm{f}_{\mathrm{z}}=0.3 \mathrm{~mm} /$ tooth and cutting speed $\mathrm{v}_{\mathrm{c}}=520$ $\mathrm{m} / \mathrm{min}$. The corrected peak value of acoustic pressure was $\mathrm{L}_{\text {pCpeak }}=103.97 \mathrm{~dB}$. The obtained values were rounded, in accordance to the norm, to the nearest integer. $\mathrm{L}_{\mathrm{pA}}=87 \mathrm{~dB}$ and $\mathrm{L}_{\mathrm{pCpeak}}=104 \mathrm{~dB}$ 
are regarded as the final results of the measurements. The maximum recorded values concern the space around the machine where the operator works. Therefore, if an operator remains at his workstation for a long time, it is necessary to use various means of noise reduction. Otherwise, it is necessary for the operators to use individual hearing protection, i.e. earmuffs or earplugs. Taking into consideration the effect of noise on human organism, prolonged operation of a CNC machine requires the use of hearing protection by the operators. The information contained in the noise parameter changes are symptoms of machine failure, clearances, overloads or improper functioning of the machine.

\section{REFERENCES}

1. Augustyńska D., Pleban D., Mikulski W.: Hałas maszyn - znormalizowane metody wyznaczania poziomu mocy akustycznej. Bezpieczeństwo Pracy, 2-3, 2000.

2. Błasiak M., Mięsikowska M., Nowakowski Ł.: Analiza zmian poziomu ciśnienia akustycznego wrzeciona obrabiarki w strefie pracy operatora. Mechanik, 8-9, 2015, 390-398.

3. Bryła R.: Ocena ryzyka zawodowego na stanow $\neg$ isku obróbki skrawaniem metali. Stal Metale i Nowe Technologie, 2007, 5-6.

4. Engel Z., Pleban D.: Hałas Maszyn i Urządzeń źródła, ocena. CIOP, Warszawa, 2001.

5. Girvin R.: Aircraft Noise-Abatement and Mitigation Strategies. J. of Air Transport Management 15, 2009, 14-22.

6. Glowacz A.: Diagnostics of direct current machine based on analysis of acoustic signals with the use of symlet wavelet transform and modified classifier based on words, Eksploatacja i Niezawodność. Maintenance and Reliability, 16 (4), 2014, 554-558.

7. Glowacz A., Glowacz A., Korohoda P.: Recognition of monochrome thermal images of synchronous motor with the application of binarization and nearest mean classifier, Archives of Metallurgy and Materials, 59, 1, 2014, 31-34.

8. Jemielniak K., Kosmol J.: Tool and Process Monitoring - State of Art and Future Prospects. Scientific Papers of the Inst. of Mech. Engng. and Automation of the Technical Univ. of Wroclaw, 61, 1995, 90-112.

9. Jemielniak K. Obróbka wysokoczęstotliwościowych sygnałów emisji akustycznej pochodzącej z procesu skrawania. Postępy Technologii Maszyn i Urządzeń, 18 (4), 1994, 21-29.

10. Józwik J., Czwarnowski M.: Angular positioning accuracy of rotary table and repeatability of fiveaxis machining centre dmu 65 monoblock. Advances in Science and Technology Research Journal, 9 (28), 2015, 89-95.

11. Józwik J., Mika D.: Diagnostics of workpiece surface condition based on cutting tool vibrations during machining, Advances in Science and Technology Research Journal, 9 (26), 2015, 57-65.

12. Józwik J., Pietras P.: Investigation and Assessment of Occupational Risk on the Metal Cutting Machine Tool Stand. Advances in Science and Technology Research Journal, 7 (20), 2013, 47-54.

13. Józwik J., Semotiuk L., Kuric I.: Diagnostic of CNC Lathe with QC 20 Ballbar system. Advances in Science and Technology Research Journal, 9 (28), 2015, 96-102.

14. Krolczyk G., Krolczyk J., Legutko S., Hunjet A. Effect of the disc processing technology on the vibration level of the chipper during operations process, Tehnicki Vjesnik - Technical Gazette, 21 (2), 2014, 447 - 450.

15. Krolczyk G.M., Nieslony P., Krolczyk J.B., Samardzic I., Legutko S., Hloch S., Barrans S., Maruda R.W. Influence of argon pollution on the weld Surface Morphology, Measurement, 70, 2015, 203-213.

16. Marchuk V.I., Ravenets L.M., Marchuk S.V., Świć A., Mechanism of origin of structural vibrations in conical roller BEARINGS Advances in Science and Technology Research Journal, 8 (23), Sept. 2014, 68-72.

17. Maruda R., Legutko S., Krolczyk G., Hloch S., Michalski M. An Influence of Active Additives on the Formation of Selected Indicators of the Condition of the Z10CrNi18-8 Stainless Steel Surface Layer in MQCL Conditions, International Journal of Surface Science and Engineering, 9 (5), 2015 , 452-465.

18. Miko E., Nowakowski Ł.: Vibrations In the Machining System of the Vertical Machining Center. XIIIth International Scientific And Engineering Conference Hermetic Sealing, Vibration Reliability And Ecological Safety Of Pump And Compressor Machinery-Hervicon, 2012, Tom: 39, 405-413.

19. Mikulski W., Augustyńska D., Pleban D.: Opracowanie projektów PN-EN dotyczących określenia poziomu mocy akustycznej maszyn. Zadanie badawcze 02.4.6SPR-1, CIOP, Warszawa 1999.

20. Sadowski J.: Możliwości zmniejszenia hałasu technologicznego przecinarek tarczowych do drewna. Inż. Ap. Chem, 50 (3), 2011, 71-72. 